Original article

\title{
Increased tree-growth synchronization of beech (Fagus sylvatica L.) in response to climate change in northwestern Europe
}

\author{
Nicolas Latte ${ }^{\mathrm{a}, *}$, François Lebourgeois ${ }^{\mathrm{b}, \mathrm{c}}$, Hugues Claessens ${ }^{\mathrm{a}}$ \\ a Forest Resources Management, University of Liège, Gembloux Agro-Bio Tech, Passage des Déportés 2, 5030 Gembloux, Belgium \\ b AgroParisTech, UMR1092, Laboratoire d'Étude des Ressources Forêt Bois (LERFoB), Rue Girardet 14, 54042 Nancy, France \\ ' INRA, UMR1092, Laboratoire d'Étude des Ressources Forêt-Bois (LERFoB), Centre INRA de Nancy, F-54280, Champenoux, France
}

\section{A R T I C L E I N F O}

\section{Article history:}

Received 29 October 2014

Accepted 23 January 2015

\section{Keywords:}

Radial growth

Basal area increment

Altitudinal gradient

Tree-ring analysis

Mean sensitivity

Global warming

\begin{abstract}
A B S T R A C T
To better understand how the radial growth of beech (Fagus sylvatica L.) high forests has responded to climate change, we selected 12 sites (137 trees) with optimal growing conditions along a W-E altitudinal gradient (67-590 m) in Belgium. We evaluated temporal changes in growth response to climate by using pointer year analysis, moving mean sensitivities (1860-2011), and moving bootstrapped correlation coefficients (1952-2011). The strongest driving climatic variables were identified by using the partial least squares method.

The common patterns of growth trends, pointer years, and mean sensitivities among sites provided evidences for the impact of environmental changes operating at a regional scale. The results of growth-climate analysis indicated that these changes were strongly influenced by the climatic conditions of the previous year. The climate sensitivity of beech increased progressively in response to more frequent and intense heat waves and warming-related droughts, especially during recent decades, leading to remarkable inter-site synchronization. The changes were much more pronounced for sites located in lowlands $(<300 \mathrm{~m})$. The differences in growth responses along the altitudinal gradient and the consequences of warming for beech growth and physiology are discussed.
\end{abstract}

(C) 2015 Elsevier GmbH. All rights reserved.

\section{Introduction}

Common beech (Fagus sylvatica L.) is one of the most widespread and important tree species in Europe. This species is distributed from Sicily in southern Italy to Bergen in southern Norway, and it occurs in various habitats from mountainous regions to lowlands (Fang and Lechowicz, 2006; Seynave et al., 2008). Recently, numerous tree-ring studies have revealed long-term changes in the tree-growth-climate relationships of several broadleaved and coniferous tree-species; this phenomenon is termed the "divergence problem" (D’Arrigo et al., 2008; Lebourgeois and Mérian, 2011). For beech, changes have been observed throughout Europe (Dittmar et al., 2003; Jump et al., 2006; Di Filippo et al., 2007, 2012; Friedrichs et al., 2009; Bolte et al., 2010; Scharnweber et al., 2011; Lebourgeois et al., 2012; van der Maaten, 2012; Weber et al., 2013; Castagneri et al., 2014). At high-elevation and/or high-latitude sites, temperature is the key driving factor of tree growth and observed

\footnotetext{
* Corresponding author. Tel.: +32 81622 515; fax: +32 81622301.

E-mail address: nicolas.latte@ulg.ac.be (N. Latte).
}

changes in the tree-growth-climate relationships correspond to a loss of response to temperature. At mid- and low-latitude sites, tree growth is dependent on the interaction between temperature and water availability (Lebourgeois and Mérian, 2011). Thus, to disentangle the specific warming effect of water availability on beech, it seems more appropriate to sample trees from stands with optimal growing conditions. Changes in temperature thresholds in these stands might play a major role in influencing carbon stock (Latte et al., 2013), carbon uptake projections (De Vries et al., 2006; Campioli et al., 2012) and management policies; moreover, they may induce severe economic losses (Hanewinkel et al., 2013).

Since the 1990s, anomalies in beech health (e.g., worsening crown conditions) have been observed throughout Europe (UNECE, 2005) and in Belgium (Laurent and Lecomte, 2007). During the same period, beech height growth and productivity changes have been reported in Belgium (Kint et al., 2012; Aertsen et al., 2014) and northeastern France (Bontemps et al., 2010; Charru et al., 2010). Beech is sensitive to drought during the period between budburst and the month of July and also to summer heat waves (Mund et al., 2010; Scharnweber et al., 2011). These factors are considered to be the major limiting abiotic disturbances for beech in Belgium in the 
context of climate change (Campioli et al., 2012). Since the end of the 19 th century, precipitation has remained relatively stable over time; however, temperatures have increased by approximately $2{ }^{\circ} \mathrm{C}$ (Demarée et al., 2002) and will likely continue to increase in the future (Baguis et al., 2010; Collins et al., 2013). The higher frequency and intensity of heat waves and warming-related droughts have altered tree functioning and will probably continue to do so (Bréda et al., 2006; McDowell, 2011); this will be particularly true at sites with lower water availability, where beech is more sensitive to climate (Lebourgeois et al., 2005). Thus, niche-based models forecast a reduction in the beech distribution area during the $21 \mathrm{st}$ century, especially for lowlands in northwestern Europe (Piedallu et al., 2009; Kramer et al., 2010).

In the present study, we evaluated the influence of global warning on the tree-growth-climate relationships of northwestern European beech forests. We selected 12 beech stands along the entire altitudinal and climatic gradient of southern Belgium. To specifically investigate the effect of warming along the gradient, we defined the selection criteria so as to minimize differences between stands and growing conditions, as well as to reduce the effects of interactions between warming and water availability. Our hypotheses were that (1) global warming and related heat waves have progressively affected beech, thereby reducing its growth and increasing its sensitivity, and (2) resulting changes in growth responses to climate should vary with altitude and are probably more intense in lowlands.

\section{Materials and methods}

\section{Study area and site and tree selection}

Twelve beech stands were selected along a W-E gradient in Belgium (Fig. 1), spanning the entire elevation gradient from the lowlands (67 m) to the Ardennes Plateau (590 m). Along this gradient, the mean annual temperature decreases (from $10.3^{\circ} \mathrm{C}$ to $7.2^{\circ} \mathrm{C}$ ) and the annual precipitation increases (from $743 \mathrm{~mm}$ to $1047 \mathrm{~mm}$; Table 1). We restricted our stand selection to sites that were optimal for beech growth and had no noticeable topographic or soil constraints (slope $\leq 3 \%$ ). Thus, the selected stands were among the most productive in Europe (dominant height of 19-30 $\mathrm{m}$ at the age of 80 years; Table 1). Soil boreholes were used to roughly estimate the maximal soil water content ( $\geq 90 \mathrm{~mm}$; Table 1 ) based on the soil texture, stoniness, and depth (Ridremont et al., 2011). In addition, we limited our sampling to a fixed silvicultural context of mature and dominant trees within pure beech forests $(>75 \%$ of basal area) that had been managed according to an even-aged (or regular) structure by forest administration for more than half a century. The selection criteria were thus defined to minimize differences between stands and site growing conditions, in order to focus on the influence of temperature along the altitudinal gradient. We restricted our stand selection to stands ranging in age from 84 years old to 206 years old (Table 1 ), in order to focus on mature trees and eliminate juvenile and senescence effects.

In each beech site, 8-15 dominant or co-dominant healthy beech trees of comparable dimensions were selected (137 trees, Table 1) and cut down in the winter of 2011-2012. One disk per tree was collected at breast height $(1.3 \mathrm{~m})$ at eight sites, and because of technical constraints, from higher up the stem at four sites (Table 1 ). The variation in sampling height did not markedly influence the results or their interpretation (Supplementary material: Figs. A and B). To facilitate handling, two bars (each $12 \mathrm{~cm}$ wide) were extracted from opposite side of the disk. Bars represent a good compromise between disks and cores. Bar dimensions are more practical than disks for sample preparation; moreover,

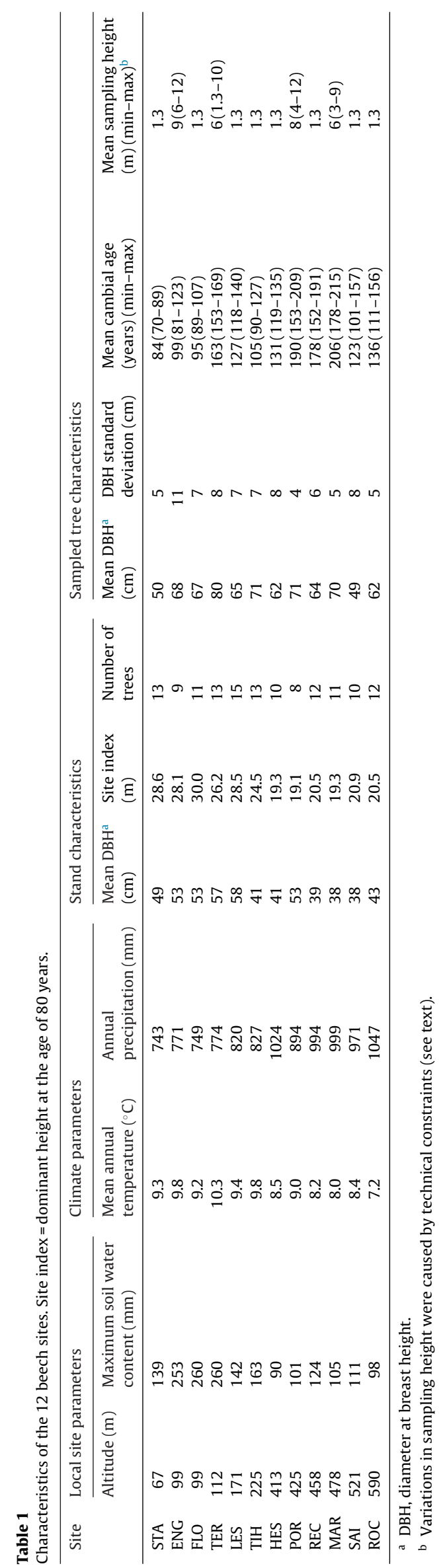




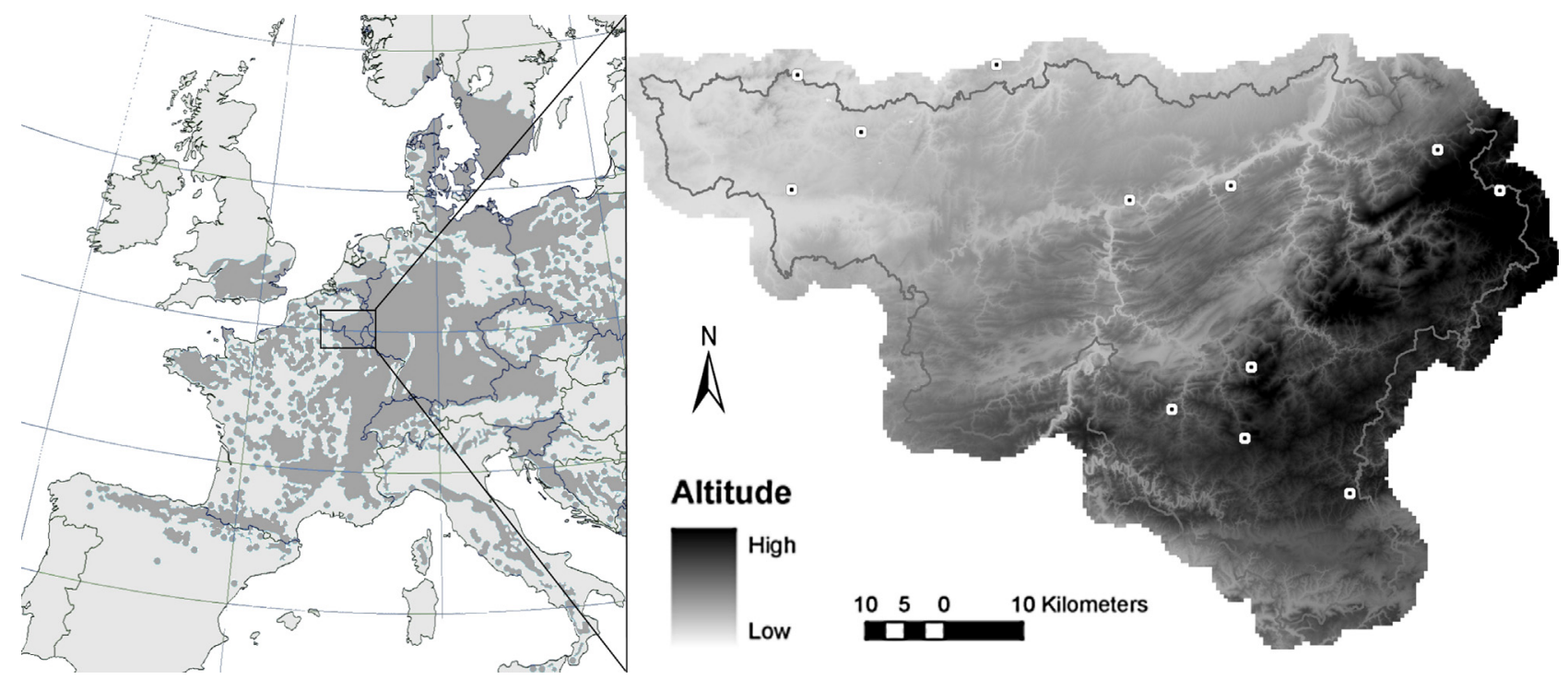

Fig. 1. Distribution map of Fagus sylvatica in Europe (source: www.euforgen.org) and locations of the 12 beech sites (white dots) in southern Belgium.

in comparison with cores, their higher area improves ring delineation and overall measurement quality. We ensured that the selection criteria of sites and trees (Mérian and Lebourgeois, 2011a; Mérian et al., 2013) and the resulting tree-ring series (Mérian and Lebourgeois, 2011b) met the requirements for being representative of beech growth at the scale of the study region.

\section{Tree-ring measurement and chronology building}

Air-dried bars were planed, sanded (grit 80-180), and scanned at high resolution ( $\geq 1200 \mathrm{dpi}$ ). Tree-ring widths were measured on each bar from the core to the pith with an accuracy of $1 / 100 \mathrm{~mm}$ by using WinDENDRO (Regent Instruments Canada Inc., 2009). Individual ring-width series were carefully cross-dated by progressively detecting the pointer years following Cropper's method (Cropper, 1979) as described in Neuwirth et al. (2007). A pointer year was defined as positive (or negative) when the normalized Cropper's values of at least $50 \%$ of the trees were larger (or smaller) than +1 (or -1 ). According to the density function of the normal distribution, the probability for a positive (or negative) growth anomaly is $<16 \%$. The cross-dating was validated for the period 1860-2011, by using available reference chronologies for Belgium (Penninckx et al., 1999; Supplementary material: Fig. C) and regional pointer years (Kint et al., 2012).

To enable more accurate quantification of wood production, ring width was converted into basal area increment (BAI) (Michelot et al., 2012; Weber et al., 2013). Site-specific chronology building and statistical calculations were conducted on BAI by using $R$ ( $R$ Core Team, 2012) and the "dplR" package (Bunn, 2008). Individual bar series were detrended with a flexible cubic smoothing spline (frequency response of $50 \%$ at a wavelength of 24 years), to minimize low and medium frequencies caused by age, competition, and silviculture (Cook and Kairiukstis, 1990). The raw and detrended individual series were averaged by site.

Chronology statistics were computed for the common overlap period 1943-2011 (a minimum of five available trees for each site). The chronology quality was evaluated by using the expressed population signal (EPS) and the effective signal (ES). The EPS quantifies how well a chronology based on a finite number of trees represents the hypothetical perfect or true chronology, and the ES estimates the signal strength within and between trees (Wigley et al., 1984). The first-order auto-correlation coefficient
(AC) assesses the influence of the previous year's growth on the current year's growth. The mean sensitivity (MS) estimates the year-to-year variability caused primarily by climatic fluctuations. The temporal variation in site MS was calculated in a moving window of 30 years, from 1860 to 2011. The mean change in MS during the period 1943-2011 was estimated as the slope of the single linear regression of the moving 30-year MS.

\section{Meteorological data}

For each site, the daily mean, minimum, and maximum temperatures ( $T_{\text {mean }}, T_{\text {min }}$, and $T_{\max }$, respectively, in ${ }^{\circ} \mathrm{C}$ ), and precipitation $(P$, in $\mathrm{mm}$ ) from 1950 to 2011 were extracted from the gridded version $(0.25 \mathrm{deg})$ of the European Climate Assessment Dataset (Haylock et al., 2008). The Hargreaves' potential evapotranspiration (PET) according to the formulation of Droogers and Allen (2002) and the climatic water balance $(\mathrm{WB}=P-\mathrm{PET}$ ) were computed daily. Single and multi-month climatic variables were obtained by averaging the daily values of $T_{\text {mean }}, T_{\min }$, and $T_{\max }$ and by summing the daily values of $P$, PET, and WB for periods of one to seven month(s). The final month of these periods ranged from April of the previous year to October of the current year. We computed 798 variables for the period 1952-2011.

\section{Climate-tree-growth analysis}

The climate-growth relationships were analyzed for the period 1952-2011 by using R ( $R$ Core Team, 2012) in two steps. First, the best explanatory variables common to all sites were identified by using the partial least squares (PLS) regression method (R package "pls"; Mevik and Wehrens, 2007). This statistical method can be used to describe the fundamental relations between the BAI indices $(Y)$ and the matrix of climatic variables $(X)$, by combining the principles of principal component analysis and multiple linear regression $(\mathrm{Y}=\mathrm{f}(\mathrm{X}))$. It is particularly appropriate when there are more $X$ variables than observations (i.e., number of years) and when there is multicollinearity among $X$ variables (Mevik and Wehrens, 2007). PLS regressions (single component) were computed between the BAI indices and standardized climatic variables (mean, 0 ; standard deviation, 1) for (1) all sites together, to identify the best common variables, and (2) site by site, to ensure that the identified common variables were among the best variables for each site individually. 

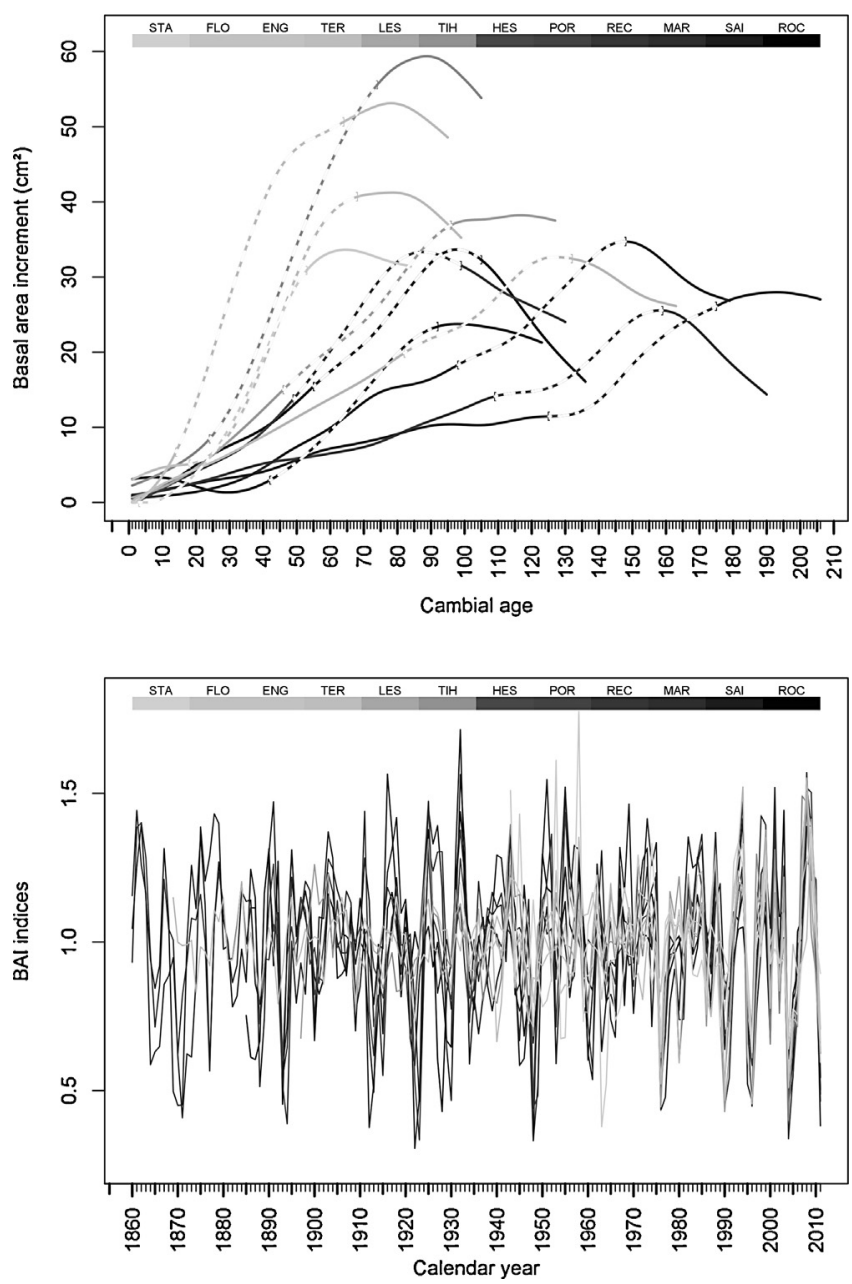

Fig. 2. Top, trends in the basal area increment (BAI) of the 12 beech sites with age (spline with a frequency response of $50 \%$ at a wavelength of 48 years). Dashed lines indicate the period 1930-1980. Bottom, BAI indices of the 12 beech sites for the period 1860-2011. Darker gray indicates higher altitudes (range, 67-590 m).

According to the variable importance in projection (Chong and Jun, 2005), one variable was selected for each data type (temperature: $T_{\text {mean }}, T_{\min }$, and $T_{\max }$, and water availability: $P$, PET, and WB). Next, the bootstrapped correlation coefficients (BCCs) between the selected variables and the site BAI index chronologies were computed by using the R package "bootRes" (Zang and Biondi, 2013) in a 30-year moving window for the period 1952-2011. The statistical significance was tested by using the bootstrap method with a $95 \%$ confidence interval (Efron and Tibshirani, 1986).

\section{Results}

Tree-ring chronologies: quality and pattern

The EPS ranged from 0.86 to 0.96 (mean $=0.93$ ), indicating that each site chronology adequately represented the population of (co-)dominant trees (Table 2). The ES ranged from 0.40 to 0.67 (mean $=0.53$ ), indicating that the between-trees and within-trees signals were strong. The MS values (0.14-0.30) demonstrated a relatively strong inter-annual variability within tree-ring indices. The AC values (0.41-0.87) revealed a high dependency of the current year's growth on the previous year's growth. The BAIs of the 12 beech sites were in proportion to the site index (Table 1 ) and showed a similar pattern of change over time (Fig. 2, top). The growth rate accelerated between the 1930s and the 1970s, and thereafter, strongly decelerated.

\section{Pointer year analysis}

For the common period 1943-2011, the number of positive and negative pointer years (PYs) ranged from 5 to 20 according to site; moreover, negative PYs occurred more frequently than positive PYs (Table 2). From 1860 to the beginning of the 1990s (Fig. 3), the proportion of sites with common PYs was <75\% (except in 1976). During the two last decades, a much higher frequency of PYs (particularly negative PYs) was observed; $58 \%$ of PYs occurring from 1943 to 2011 were concentrated during the period 1990-2011. Six negative PYs were common to at least eight sites as follows: 1948 (9), 1976 (11), 1990 (8), 1996 (12), 2004 (11), and 2011 (11). There were many points of convergence between these major PYs and extreme climatic events in Belgium (Institut Royal Météorologique (IRM), 2000). The main growth losses were observed during the current year if drought occurred in spring (e.g., 1990, 2011) or during the following year if a heat wave (and drought) occurred in summer (e.g., 1948, 2004). Exceptional growth losses were induced by the combined effects of stressful growing conditions during the previous summer and current spring $(1976,1996)$. Positive years were generally related to favorable conditions in the previous summer (wet and/or cool).

\section{Mean sensitivity increase and growth synchronization}

For the period 1860-2011, the mean sensitivity (MS) varied according to the site altitude (Fig. 4). Before the 1970s, the MS of lower altitude (LA, $<300 \mathrm{~m}$ ) sites was lower than that of higher altitude (HA, >400 m) sites; this phenomenon occurred despite the fact that LA sites had lower precipitation and warmer temperatures but higher soil water contents than did the HA sites (Table 1). After the 1970s, the MS of LA sites (with the exception of STA) increased more intensely to reach the same level as that of the HA sites.

For the common period 1943-2011, the MS was higher for older stands at LA and HA sites; however, the MS changes differed between the LA and HA sites (Fig. 4). The MS increases were higher for older stands at LA sites and for younger stands at HA sites. During the same period, the $12 \mathrm{BAI}$ index chronologies (Fig. 2, bottom) became increasingly synchronized, leading to a strong increase in the inter-site correlation for the two altitude groups (Fig. 5).

\section{Climate-tree-growth relationships}

For the period 1952-2011, the $r$-square of the "all sites" PLS was $21 \%$, and the $r$-square values of the "site by site" PLSs ranged from $17 \%$ to $39 \%$ and were systematically higher for the HA sites (Table 2). The main driving climatic variables were the same for the "all sites" PLS and the mean of the 12 "site by site" PLSs and were (1) the mean of the daily maximum temperature from July to October of the previous year (TMAX), and (2) the sum of the daily climatic water balance from May to November of the previous year (CWB). The remaining variables did not explain a significant part of the common inter-site growth variation.

The bootstrapped correlation coefficient (BCC) between the 12 BAI index chronologies and the best explanatory variables was significant for the period 1952-2011; moreover, pronounced changes were observed over time (Fig. 6). For TMAX, all sites showed a similar pattern, with a strong increase in the absolute BCC toward the end of the 1970s, followed by high and significant values. From 1952 to 2011, the mean TMAX (all sites) increased continually by $+0.8^{\circ} \mathrm{C}\left(+1.4^{\circ} \mathrm{C}\right.$ in July and August $)$. The $10-90$ th percentile range of TMAX also increased, but to a much larger extent (up to +40\%) at LA 
Table 2

Statistics of the raw and detrended chronologies of the 12 beech sites for the common period 1943-2011.

\begin{tabular}{|c|c|c|c|c|c|c|c|c|c|}
\hline \multirow[t]{2}{*}{ Site } & \multicolumn{3}{|c|}{ Non-detrended chronologies } & \multicolumn{2}{|c|}{ Number of pointer years } & \multicolumn{3}{|c|}{ Detrended chronologies } & \multirow{2}{*}{$\begin{array}{l}R \text {-square } \\
\text { PLS (\%) }\end{array}$} \\
\hline & $\begin{array}{l}\text { Averaged } \\
\text { BAI } \\
\left(\mathrm{cm}^{2} / \text { year }\right)\end{array}$ & $\begin{array}{l}\text { Averaged } \\
\text { ring-width } \\
\text { (mm/year) }\end{array}$ & $\begin{array}{l}\text { First-order } \\
\text { auto-correlation } \\
\text { coefficient }(A C)\end{array}$ & Negative & Positive & $\begin{array}{l}\text { Mean } \\
\text { sensitivity } \\
\text { (MS) }\end{array}$ & $\begin{array}{l}\text { Effective } \\
\text { signal (ES) }\end{array}$ & $\begin{array}{l}\text { Expressed } \\
\text { population } \\
\text { signal (EPS) }\end{array}$ & \\
\hline STA & 22.9 & 2.7 & 0.87 & 6 & 5 & 0.24 & 0.54 & 0.94 & 17 \\
\hline ENG & 46.5 & 3.0 & 0.58 & 3 & 2 & 0.14 & 0.41 & 0.86 & 17 \\
\hline FLO & 33.2 & 3.2 & 0.81 & 7 & 5 & 0.14 & 0.40 & 0.89 & 18 \\
\hline TER & 28.6 & 2.1 & 0.41 & 10 & 7 & 0.24 & 0.53 & 0.94 & 31 \\
\hline LES & 32.5 & 2.3 & 0.54 & 9 & 5 & 0.23 & 0.51 & 0.94 & 39 \\
\hline $\mathrm{TIH}$ & 47.8 & 3.0 & 0.57 & 8 & 5 & 0.21 & 0.56 & 0.94 & 32 \\
\hline HES & 28.8 & 2.2 & 0.49 & 10 & 10 & 0.24 & 0.66 & 0.95 & 27 \\
\hline POR & 20.1 & 1.6 & 0.56 & 11 & 7 & 0.28 & 0.54 & 0.92 & 33 \\
\hline REC & 29.1 & 1.7 & 0.42 & 10 & 4 & 0.29 & 0.54 & 0.94 & 38 \\
\hline MAR & 23.5 & 1.5 & 0.59 & 11 & 7 & 0.30 & 0.67 & 0.96 & 39 \\
\hline SAI & 19.2 & 1.7 & 0.73 & 5 & 5 & 0.19 & 0.51 & 0.91 & 34 \\
\hline ROC & 26.3 & 2.0 & 0.60 & 8 & 6 & 0.23 & 0.53 & 0.93 & 29 \\
\hline All sites & 29.9 & 2.2 & 0.60 & 8.2 & 5.7 & 0.23 & 0.53 & 0.93 & 29 \\
\hline $\begin{array}{l}\text { Lower elevation sites } \\
\qquad(<300 \mathrm{~m})\end{array}$ & 35.2 & 2.7 & 0.63 & 7.2 & 4.8 & 0.20 & 0.49 & 0.92 & 26 \\
\hline $\begin{array}{l}\text { Higher elevation sites } \\
\qquad(>400 \mathrm{~m})\end{array}$ & 24.5 & 1.8 & 0.56 & 9.2 & 6.5 & 0.26 & 0.58 & 0.94 & 33 \\
\hline
\end{tabular}

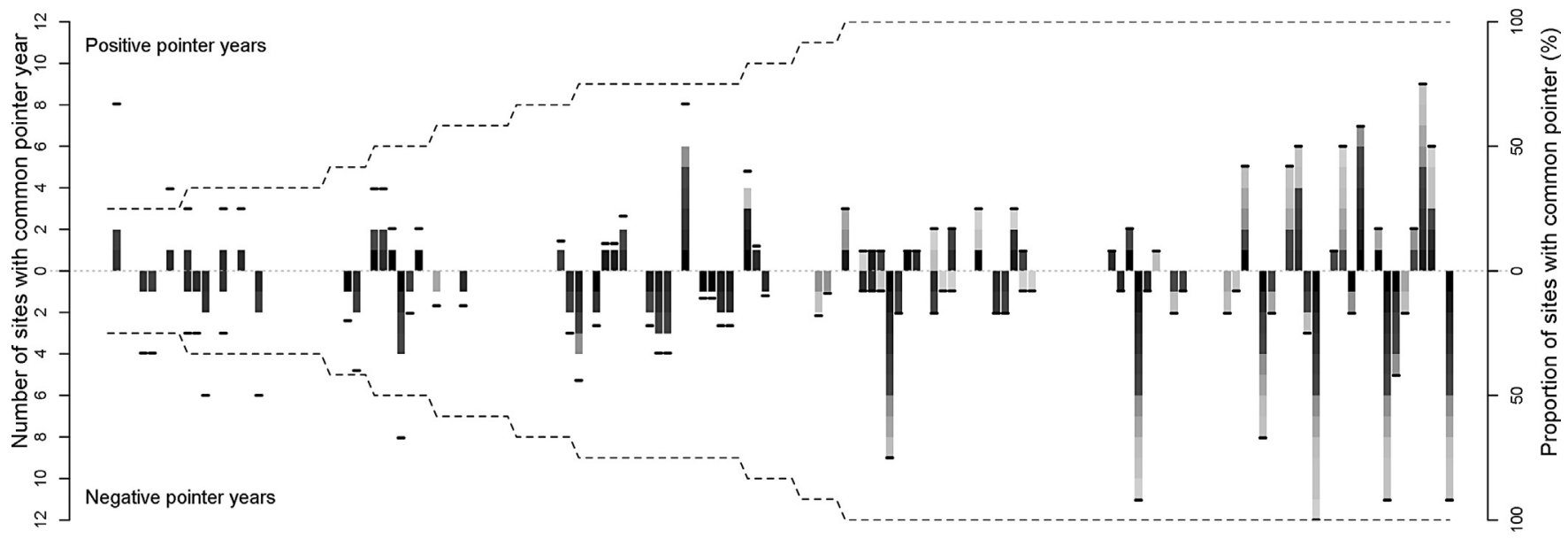

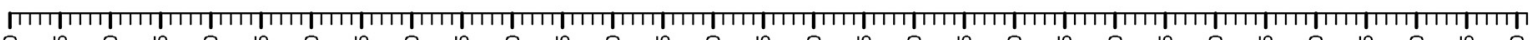

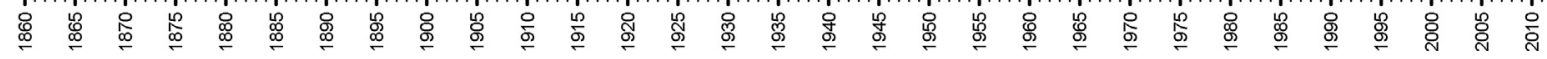

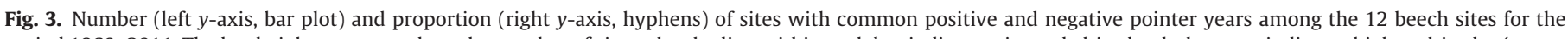

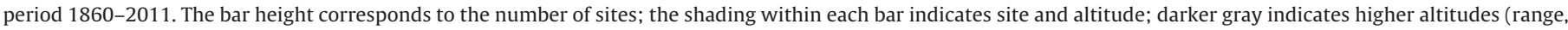
$67-590 \mathrm{~m}$ ). The dotted lines correspond to the number of sites (sample depth) with at least five trees available by site.

sites. For CWB, the mean value remained relatively constant over time; however, the BCCs increased for all sites. The three youngest LA sites (FLO, STA, and ENG) showed significant BCC values later than did the other investigated sites (Fig. 6) and this confirmed the smaller MS increase for young stands at LA sites (Fig. 4).

\section{Discussion}

In the present study, the common patterns of basal area increment (Fig. 2), negative pointer years (Fig. 3), mean sensitivity (Fig. 4), inter-site correlations (Fig. 5), and bootstrapped correlations (Fig. 6) along the altitudinal gradient provide evidence for the impact of environmental changes on beech at a regional scale.

The overall growth increase observed at the European scale before the 1970s has frequently been attributed to increasing temperatures combined with nitrogen deposition and increasing atmospheric $\mathrm{CO}_{2}$, as well as to changes in forest management (e.g., De Vries et al., 2006; Bontemps et al., 2009, 2011). The stand selection was oriented toward reducing the impact of forest management as much as possible. However, historical documents mention that before the 1950s, beech stands were generally managed at high density (e.g., a 24-year or less frequent thinning cycle) and that subsequent forest administration intensified the use of silvicultural practices (e.g., a 12-year thinning cycle). Previous studies reported that thinning can enhance the growth and resilience of mature beech trees (Le Goff and Ottorini, 1999; van der Maaten, 2013). Therefore, changes in forest management after the 1950 s may partly explain the observed growth increase before the 1970s.

After the 1970s, the observed growth decrease is consistent with the results of recent studies on beech productivity in northern Belgium (Kint et al., 2012; Aertsen et al., 2014) and northeastern France (Bontemps et al., 2010; Charru et al., 2010). Tree-ring studies of beech in different regions of Europe also reported decreasing radial growth and increasing climate sensitivity (Dittmar et al., 

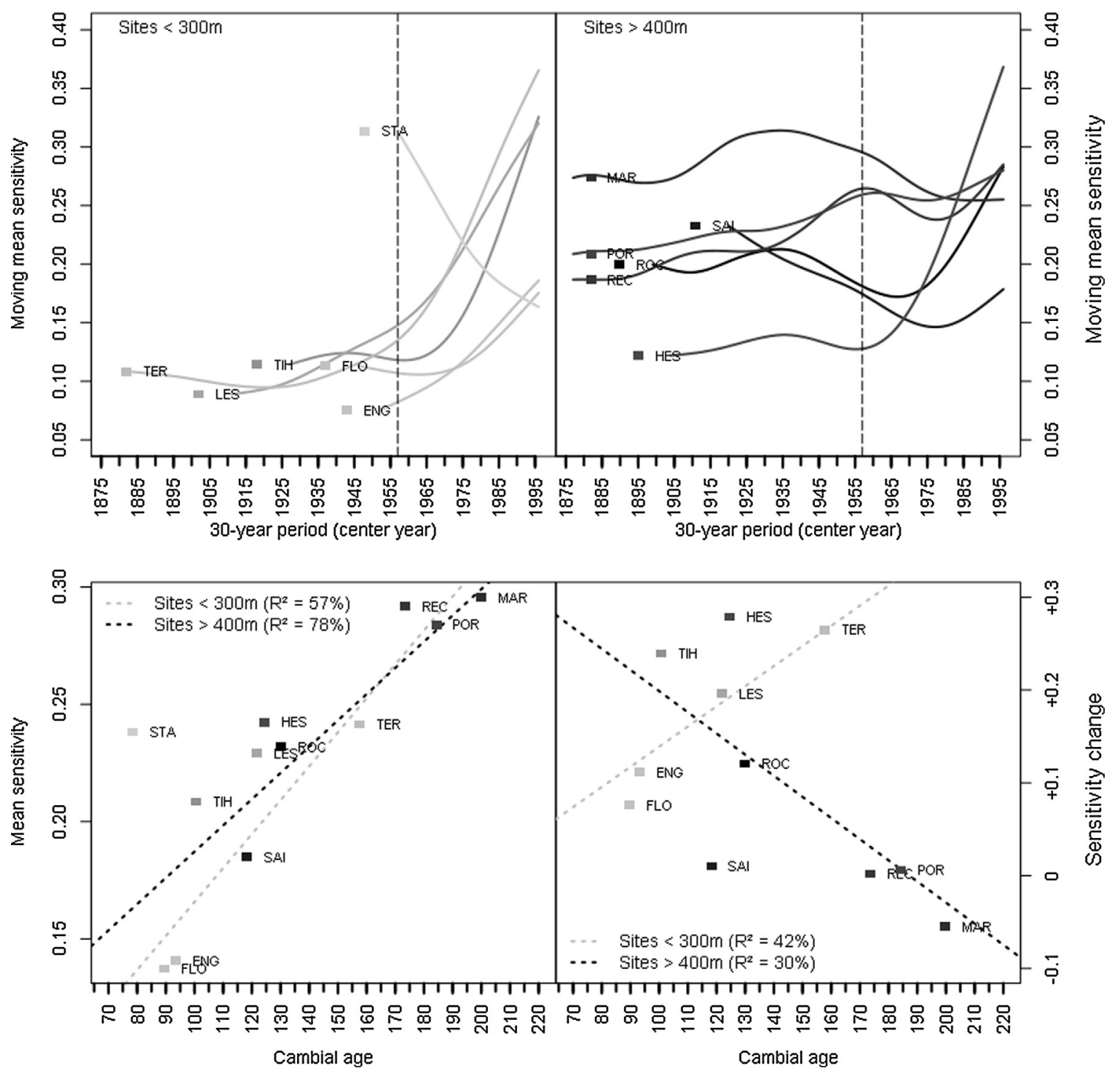

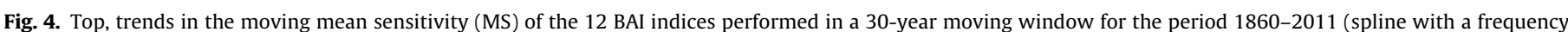

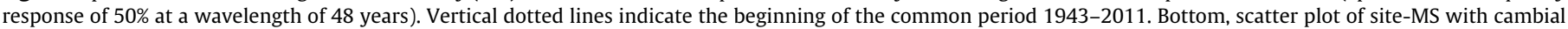
age (left), and its change over time (right) for the period 1943-2011. Dotted lines correspond to single linear regressions excluding the STA site.

2003; Jump et al., 2006; Di Filippo et al., 2007, 2012; Friedrichs et al., 2009; Scharnweber et al., 2011; Lebourgeois et al., 2012; van der Maaten, 2012; Weber et al., 2013; Castagneri et al., 2014), except in high mountains (Di Filippo et al., 2012) and at high latitudes (Bolte et al., 2010). However, the rapidly decreasing growth that occurred uniformly along the climatic gradient was unexpected, because the stands were selected at sites that were optimal for beech growth, had no noticeable topographic and soil constraints, and were located in an area that was distant from the distribution limit; these stands were among the most productive in Europe.

On the basis of the continuity after the 1950s, the growth decline cannot be explained by forest management. The aging of trees is frequently related to a decline in forest productivity and is characterized by an increase in sensitivity to perturbations (Genet et al., 2009). The results of our present study confirm the increasing sensitivity of beech with age at the regional scale; however, the influence of aging on sensitivity changes over time was inconsistent along the altitudinal gradient. On average, the sensitivity of older stands ( $>160$ years old) remained stable, whereas it increased for the remaining stands. Our findings indicate that the influence of aging is limited and cannot solely explain the observed changes. This assumption is reinforced by the fact that the sensitivity increase was triggered in a large range of tree ages (70-215 years) during a relatively short period. Recently, Kint et al. (2012) reported a negative effect of excess nitrogen deposition on beech productivity in northern Belgium; however, climate variables (particularly decreasing air humidity and increasing temperature) were essential for modeling the growth decrease. Furthermore, growth declines were observed in other regions of northwestern Europe (Bontemps et al., 2010; Charru et al., 2010), where the rate of nitrogen deposition was lower than in Belgium (De Vries et al., 2003).

The results of correlation analysis clearly revealed the increasing influence of the previous year's climatic conditions (Dittmar et al., 2003; Lebourgeois et al., 2005; Friedrichs et al., 2009; Härdtle et al., 2013). Several ecophysiological hypotheses can be used to explain the negative impact of warmer temperatures during summer and at the start of autumn. (1) Increasingly high temperatures exacerbate the effects of heat waves and droughts on beech growth (Lebourgeois et al., 2005) and vitality (Bréda et al., 2006), and therefore increase the risk of hydraulic failure (McDowell, 2011). Beech 


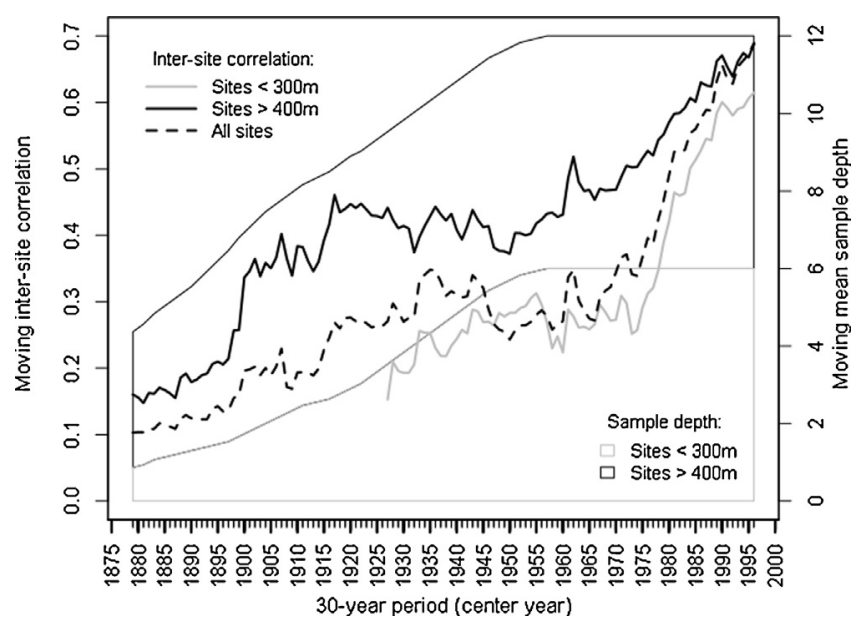

Fig. 5. Left y-axis, inter-site correlation coefficient between the BAI indices of at least two sites at lower altitudes $(<300 \mathrm{~m}$, in gray) and higher altitudes $(>400 \mathrm{~m}$, in black) performed in a 30-year moving window for the period 1860-2011. Right $y$-axis, mean number of sites available (with at least five trees) for the considered year.

defoliation is particularly high in a year following a warm summer, and leaf area is frequently lower for several years following a severe drought (Seidling, 2007). (2) Warmer autumnal temperatures extend beech canopy duration (Vitasse et al., 2009) and this may limit the formation of metabolic reserves (because respiration exceeds photosynthesis) and consequently growth in the following year (Michelot et al., 2012). (3) Fine roots of beech trees have a very high turnover rate in dry years (Meier and Leuschner, 2008). Thus, a higher frequency of warming-related droughts may reduce the amount of carbohydrates available for growth and to restore fine root stock for water uptake (Genet et al., 2009). (4) High temperatures (Drobyshev et al., 2010; Mund et al., 2010) and drought (Piovesan and Adams, 2001) in the summer can trigger beech masting in the following year. Thus, the observed higher frequency of masting (data not published) may accentuate the carbon depletion.

In the present study, the mean and variability of high temperatures in summer and autumn increased over time, whereas the water balance during the growing season remained relatively stable. Thus, increasing sensitivity was most likely driven by the higher frequency and intensity of heat waves and warming-related droughts. The results of pointer year analysis confirmed that the more frequent growth losses, which occurred uniformly at the regional scale, led to a pronounced inter-site synchronization. After the 1990s, the synchronization was so high that the site chronologies could be interpreted as tree chronologies of a unique stand. This trend may have been accentuated by tropospheric ozone (Dittmar et al., 2003; Matyssek et al., 2010). Concentrations of tropospheric ozone are strongly correlated with high temperatures (Stathopoulou et al., 2008) and have increased in Belgium because of increasing air pollution (De Vries et al., 2003). The
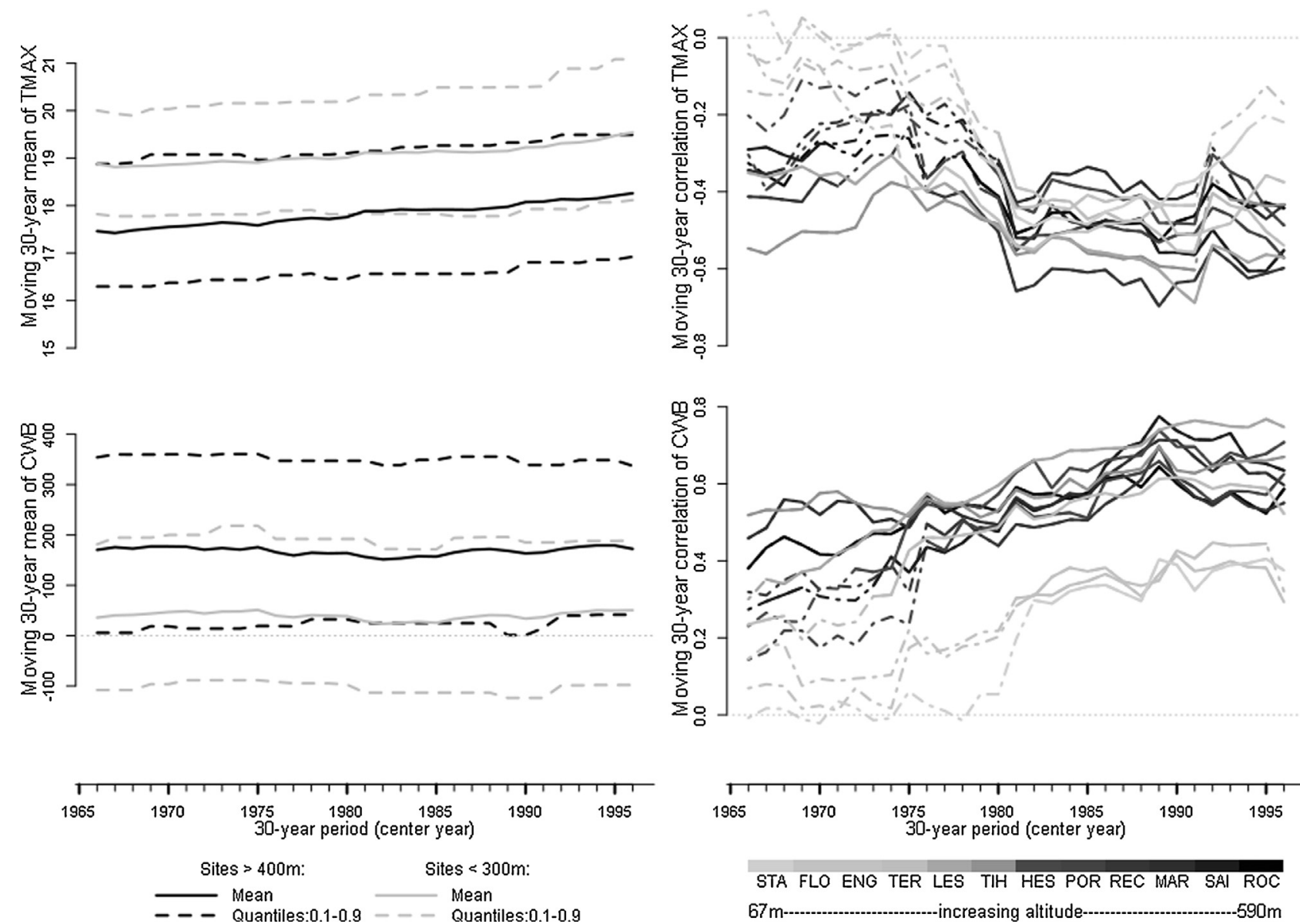

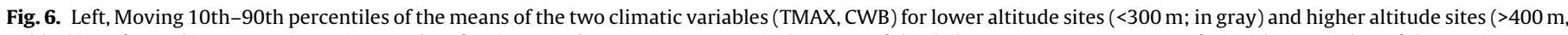

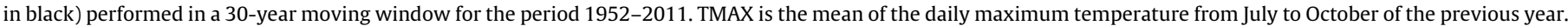

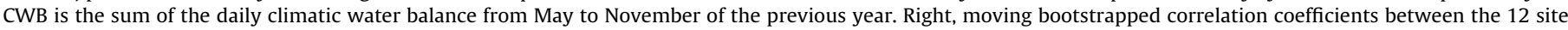

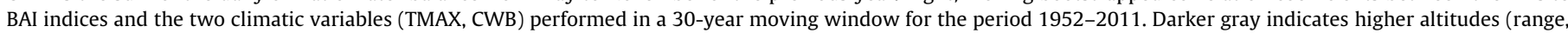
$67-590 \mathrm{~m}$ ). Solid lines indicate a significant correlation with a $95 \%$ confidence interval. 
later and higher synchronization observed in lowlands may have been induced by higher temperature variability and/or differences in water availability. The higher maximal soil water content (but lower precipitation) at lower altitudes may have ceased to mitigate the warming effects later than at higher altitudes. Our results are in accordance with those of Friedrichs et al. (2009) and Weber et al. (2013), who reported that recent changes in beech sensitivity were more pronounced at sites with higher soil moisture.

The overall trend of decreasing growth observed during recent decades was mainly derived from the higher frequency of negative pointer years; on average, the intense growth losses were not fully compensated by the good growth rate in favorable years. However, in accordance with the observations of van der Werf et al. (2007), growth recovered in the following years, implying that, to date, beech has tolerated its changing environment. The observed changes in beech growth and response to climate at sites with optimal growing conditions indicate that the positive influence of local growing conditions ( particularly water availability) decreased with warming. Given the predicted warming on the pan-European scale, beech is likely to be affected throughout a large part of its distribution area (excluding high elevations and high latitudes).

\section{Conclusions}

In the present study, we used a dendroecological approach to investigate the influence of climate change on beech growth under optimal growing conditions (high soil fertility and high water availability) along an altitudinal gradient at a regional scale (southern Belgium). We observed common patterns of decreasing growth and pronounced increasing climate sensitivity and inter-site synchronization since the 1980-1990s. Our results provide consistent evidence that changes in the tree-growth-climate relationships are induced by more frequent and intense summer heat waves and warming-related droughts. We found that beech is becoming more strongly affected than in the past, particularly in the lowlands, where the phenomena is concomitant with a decrease in tree vitality (Laurent and Lecomte, 2007; Supplementary material: Fig. D).

\section{Acknowledgements}

This study was funded by the Walloon Region (Accord-Cadre de recherche et vulgarisation forestières). We thank the staff of the Département de la Nature et des Forêts (DNF) and the Institut Bruxellois pour la Gestion de l'Environnement (IBGE) for allowing us to conduct wood sampling. We are grateful to the technical staff of the Forest Ressources Management unit (ULg - Gembloux Agro-Bio Tech), Amaury André, Frédéric Henrotay, Benoît Mackels, and Adrien Schot, for help with disk extraction, sanding, and tree-ring measurement. We thank Benoît Jourez (Département de l'Étude du Milieu Naturel et Agricole) and Lachen Hadiy (Geprofor ASBL) for their valuable help and advice. We acknowledge the E-OBS dataset from the EU-FP6 project ENSEMBLES (http://ensembles-eu.metoffice.com) and the data providers in the ECA\&D project (http://www.ecad.eu).

\section{Appendix A. Supplementary data}

Supplementary material related to this article can be found, in the online version, at http://dx.doi.org/10.1016/j.dendro. 2015.01.002.

\section{References}

Aertsen, W., Janssen, E., Kint, V., Bontemps, J.D., Van Orshoven, J., Muys, B., 2014 Long-term growth changes of common beech (Fagus sylvatica L.) are less pronounced on highly productive sites. For. Ecol. Manage. 312, 252-259.

Baguis, P., Roulin, E., Willems, P., Ntegeka, V., 2010. Climate change scenarios for precipitation and potential evapotranspiration over central Belgium. Theor. Appl. Climatol. 99, 273-286.

Bolte, A., Hilbrig, L., Grundmann, B., Kampf, F., Brunet, J., Roloff, A., 2010. Climate change impacts on stand structure and competitive interactions in a southern Swedish spruce-beech forest. Eur. J. For. Res. 129, 261-276.

Bontemps, J.D., Hervé, J.C., Dhôte, J., 2009. Long-term changes in forest productivity: a consistent assessment in even-aged stands. For. Sci. 55, 549-564

Bontemps, J.D., Hervé, J.C., Dhôte, J.F., 2010. Dominant radial and height growth reveal comparable historical variations for common beech in north-eastern France. For. Ecol. Manage. 259, 1455-1463.

Bontemps, J.D., Hervé, J.C., Leban, J.M., Dhôte, J.F., 2011. Nitrogen footprint in a longterm observation of forest growth over the twentieth century. Trees - Struct. Funct. 25, 237-251.

Bréda, N., Huc, R., Granier, A., Dreyer, E., 2006. Temperate forest trees and stands under severe drought: a review of ecophysiological responses, adaptation processes and long-term consequences. Ann. For. Sci. 63, 625-644.

Bunn, A.G., 2008. A dendrochronology program library in R (dplR). Dendrochronologia 26, 115-124.

Campioli, M., Vincke, C., Jonard, M., Kint, V., Demarée, G., Ponette, Q., 2012. Current status and predicted impact of climate change on forest production and biogeochemistry in the temperate oceanic European zone: review and prospects for Belgium as a case study. J. For. Res. 17, 1-18.

Castagneri, D., Nola, P., Motta, R., Carrer, M., 2014. Summer climate variability over the last 250 years differently affected tree species radial growth in a mesic Fagus-Abies-Picea old-growth forest. For. Ecol. Manage. 320, 21-29.

Charru, M., Seynave, I., Morneau, F., Bontemps, J.D., 2010. Recent changes in forest productivity: an analysis of national forest inventory data for common beech (Fagus sylvatica L.) in north-eastern France. For. Ecol. Manage. 260, 864-874.

Chong, I.G., Jun, C.H., 2005. Performance of some variable selection methods when multicollinearity is present. Chemometrics and Intelligent Laboratory Systems 78, 103-112.

Collins, M., Knutti, R., Arblaster, J., et al., 2013. Long-term climate change: projections, commitments and irreversibility. In: Stocker, T.F., Qin, D., Plattner, G.K., et al. (Eds.), Climate Change 2013: The Physical Science Basis. Contribution of Working Group I to the Fifth Assessment Report of the Intergovernmental Panel on Climate Change. Cambridge University Press, Cambridge.

Cook, E.R., Kairiukstis, L.A., 1990. Methods of Dendrochronology: Applications in the Environmental Sciences. Springer, ISBN 978-0792305866.

Cropper, J.P., 1979. Tree-ring skeleton plotting by computer. Tree-Ring Bull. 39, 47-59.

D’Arrigo, R., Wilson, R., Liepert, B., Cherubini, P., 2008. On the 'divergence problem' in northern forests: a review of the tree-ring evidence and possible causes. Glob. Planet. Change 60, 289-305.

Demarée, G.R., Lachaert, P.J., Verhoeve, T., Thoen, E., 2002. The long-term daily central Belgium temperature (CBT) series (1767-1998) and early instrumental meteorological observations in Belgium. Clim. Change 53, 269-293.

De Vries, W., Reinds, G.J., Posch, M., et al., 2003. Intensive monitoring of forest ecosystems in Europe 2003 Technical report. Ec, Un/Ece, Brussels, Geneva.

De Vries, W., Reinds, G.J., Gundersen, P., Sterba, H., 2006. The impact of nitrogen deposition on carbon sequestration in European forests and forest soils. Glob. Change Biol. 12, 1151-1173.

Di Filippo, A., Biondi, F., Čufar, K., De Luis, M., Grabner, M., Maugeri, M., Presutti Saba, E., Schirone, B., Piovesan, G., 2007. Bioclimatology of beech (Fagus sylvatica L.) in the Eastern Alps: spatial and altitudinal climatic signals identified through a tree-ring network. J. Biogeogr. 34, 1873-1892.

Di Filippo, A., Biondi, F., Maugeri, M., Schirone, B., Piovesan, G., 2012. Bioclimate and growth history affect beech lifespan in the Italian Alps and Apennines. Glob. Change Biol. 18, 960-972.

Dittmar, C., Zech, W., Elling, W., 2003. Growth variations of common beech (Fagus sylvatica L.) under different climatic and environmental conditions in Europe a dendroecological study. For. Ecol. Manage. 173, 63-78.

Drobyshev, I., Övergaard, R., Saygin, I., Niklasson, M., Hickler, T., Karlsson, M., Sykes, M.T., 2010. Masting behaviour and dendrochronology of European beech (Fagus sylvatica L.) in southern Sweden. For. Ecol. Manage. 259, 2160-2171.

Droogers, P., Allen, R.G., 2002. Estimating reference evapotranspiration under inac curate data conditions. Irrig. Drain. Syst. 16, 33-45.

Efron, B., Tibshirani, R., 1986. Bootstrap methods for standard errors, confidence intervals, and other measures of statistical accuracy. Stat. Sci. 1, 54-75.

Fang, J., Lechowicz, M.J., 2006. Climatic limits for the present distribution of beech (Fagus L.) species in the world. J. Biogeogr. 33, 1804-1819.

Friedrichs, D.A., Trouet, V., Büntgen, U., Frank, D.C., Esper, J., Neuwirth, B., Löffler, J., 2009. Species-specific climate sensitivity of tree growth in Central-West Germany, Trees - Struct. Funct. 23, 729-739.

Genet, H., Bréda, N., Dufrêne, E., 2009. Age-related variation in carbon allocation at tree and stand scales in beech (Fagus sylvatica L.) and sessile oak (Quercus petraed (Matt.) Liebl.) using a chronosequence approach. Tree Physiol. 30, 177-192.

Hanewinkel, M., Cullmann, D.A., Schelhaas, M.-J., Nabuurs, G.-J., Zimmermann, N.E., 2013. Climate change may cause severe loss in the economic value of European forest land. Nat. Clim. Change 3, 203-207. 
Härdtle, W., Niemeyer, T., Assmann, T., Baiboks, S., Fichtner, A., Friedrich, U., Lang A.C., Neuwirth, B., Pfister, L., Ries, C., Schuldt, A., Simon, N., von Oheimb, G., 2013. Long-term trends in tree-ring width and isotope signatures $\left(\delta^{13} \mathrm{C}, \delta^{15} \mathrm{~N}\right)$ of Fagus sylvatica L. on soils with contrasting water supply. Ecosystems 16, 1413-1428.

Haylock, M.R., Hofstra, N., Klein Tank, A.M.G., Klok, E.J., Jones, P.D., New, M., 2008. A European daily high-resolution gridded data set of surface temperature and precipitation for 1950-2006. J. Geophys. Res.: Atmos. 113, D20119.

Institut Royal Météorologique (IRM), 2000. Les évènements météorologiques marquants depuis le début du 20ème siècle. http://www.meteo.be/meteo/ view/fr/1078912-Evenements+marquants+depuis+1901.html (accessed 01.01.13).

Jump, A.S., Hunt, J.M., Penüelas, J., 2006. Rapid climate change-related growth decline at the southern range edge of Fagus sylvatica. Glob. Change Biol. 12, 2163-2174.

Kint, V., Aertsen, W., Campioli, M., Vansteenkiste, D., Delcloo, A., Muys, B., 2012 Radial growth change of temperate tree species in response to altered regional climate and air quality in the period 1901-2008. Clim. Change 115, 343-363.

Kramer, K., Degen, B., Buschbom, J., Hickler, T., Thuiller, W., Sykes, M.T., de Winter W., 2010. Modelling exploration of the future of European beech (Fagus sylvatica L.) under climate change - Range, abundance, genetic diversity and adaptive response. For. Ecol. Manage. 259, 2213-2222.

Latte, N., Colinet, G., Fayolle, A., Lejeune, P., Hébert, J., Claessens, H., Bauwens, S. 2013. Description of a new procedure to estimate the carbon stocks of all forest pools and impact assessment of methodological choices on the estimates. Eur. J. For. Res. 132, 565-577.

Laurent, C., Lecomte, H., 2007. La santé des forêts. In: Delbeuck, C. (Ed.), Rapport analytique sur l'état de l'environnement wallon 2006-2007. Ministry of Wallonia, Namur, pp. 202-207.

Lebourgeois, F., Bréda, N., Ulrich, E., Granier, A., 2005. Climate-tree-growth relationships of European beech (Fagus sylvatica L.) in the French Permanent Plot Network (RENECOFOR). Trees - Struct. Funct. 19, 385-401.

Lebourgeois, F., Mérian, P., 2011. Has sensitivity of forest species to climate changed in the 20th century? La sensibilité au climat des arbres forestiers a-t-elle changé au cours du XXième siècle? Rev. For. Franç. 63, 17-32.

Lebourgeois, F., Mérian, P., Courdier, F., Ladier, J., Dreyfus, P., 2012. Instability of climate signal in tree-ring width in Mediterranean mountains: a multi-species analysis. Trees - Struct. Funct. 26, 715-729.

Le Goff, N., Ottorini, J.M., 1999. Effects of thinning on beech growth. Interaction with climatic factors. Effets des éclaircies sur la croissance du hêtre. Interaction avec les facteurs climatiques. Rev. For. Franc. 51, 355-364.

Matyssek, R., Wieser, G., Ceulemans, et al., 2010. Enhanced ozone strongly reduces carbon sink strength of adult beech (Fagus sylvatica) - resume from the free-ai fumigation study at Kranzberg Forest. Environ. Pollut. 158, 2527-2532.

McDowell, N.G., 2011. Mechanisms linking drought, hydraulics, carbon metabolism, and vegetation mortality. Plant Physiol. 155, 1051-1059.

Meier, I.C., Leuschner, C., 2008. Belowground drought response of European beech: fine root biomass and carbon partitioning in 14 mature stands across a precipitation gradient. Glob. Change Biol. 14, 2081-2095.

Mérian, P., Lebourgeois, F., 2011a. Size-mediated climate-growth relationships in temperate forests: a multi-species analysis. For. Ecol. Manage. 261, 1382-1391.

Mérian, P., Lebourgeois, F., 2011b. Consequences of decreasing the number of cored trees per plot on chronology statistics and climate-growth relationships: a multispecies analysis in a temperate climate. Can. J. For. Res. 41, 2413-2422.

Mérian, P., Pierrat, J.C., Lebourgeois, F., 2013. Effect of sampling effort on the regional chronology statistics and climate-growth relationships estimation. Dendrochronologia 31, 58-67.

Mevik, B.H., Wehrens, R., 2007. The PLS package: principal component and partial least squares regression in R. J. Stat. Softw. 18, 1-23.

Michelot, A., Simard, S., Rathgeber, C., Dufrêne, E., Damesin, C., 2012. Comparing the intra-annual wood formation of three European species (Fagus sylvatica, Ouercus petraea and Pinus sylvestris) as related to leaf phenology and non-structura carbohydrate dynamics. Tree Physiol. 32, 1033-1045.
Mund, M., Kutsch, W.L., Wirth, C., Kahl, T., Knohl, A., Skomarkova, M.V., Schulze, E.D. 2010. The influence of climate and fructification on the inter-annual variability of stem growth and net primary productivity in an old-growth, mixed beech forest. Tree Physiol. 30, 689-704.

Neuwirth, B., Schweingruber, F.H., Winiger, M., 2007. Spatial patterns of central European pointer years from 1901 to 1971. Dendrochronologia 24, 79-89.

Penninckx, V., Meerts, P., Herbauts, J., Gruber, W., 1999. Ring width and element concentrations in beech (Fagus sylvatica L.) from a periurban forest in central Belgium. For. Ecol. Manage. 113, 23-33.

Piedallu, C., Perez, V., Gégout, J.C., Lebourgeois, F., Bertrand, R., 2009. Potential impact of global warming on the range of spruce, fir, beech and sessile oak in France. Impact potentiel du changement climatique sur la distribution de l'Épicéa, du Sapin, du Hêtre et du Chêne sessile en France. Rev. For. Franç. 61, 567-594.

Piovesan, G., Adams, J.M., 2001. Masting behaviour in beech: linking reproduction and climatic variation. Can. J. Bot. 79, 1039-1047.

R Core Team, 2012. R: A Language and Environment for Statistical Computing. R Foundation for Statistical Computing, Vienna, Austria, ISBN 3-900051-07-0 http://www.R-project.org/

Regent Instruments Canada Inc., 2009. WINDENDRO for Tree-ring Analysis.

Ridremont, F., Lejeune, P., Claessens, H., 2011. Pragmatic assessment of the water reserve of the forest sites and mapping at the regional scale (Wallonia, Belgium). Méthode pragmatique d'évaluation de la réserve en eau des stations forestières et cartographie à l'échelle régionale (Wallonie, Belgique). Biotechnol., Agron., Soc. Environ. 15, 727-741

Scharnweber, T., Manthey, M., Criegee, C., Bauwe, A., Schröder, C., Wilmking, M., 2011. Drought matters - declining precipitation influences growth of Fagus sylvatica L. and Quercus robur L. in north-eastern Germany. For. Ecol. Manage. 262, 947-961, http://dx.doi.org/10.1016/j.foreco.2011.05.026.

Seidling, W., 2007. Signals of summer drought in crown condition data from the German Level I network. Eur. J. For. Res. 126, 529-544.

Seynave, I., Gégout, J.C., Hervé, J.C., Dhôte, J.F., 2008. Is the spatial distribution of European beech (Fagus sylvatica L.) limited by its potential height growth? J. Biogeogr. 35, 1851-1862.

Stathopoulou, E., Mihalakakou, G., Santamouris, M., Bagiorgas, H.S., 2008. On the impact of temperature on tropospheric ozone concentration levels in urban environments. J. Earth Syst. Sci. 117, 227-236.

UNECE, 2005. The condition of forests in Europe. In: Executive Report. UNECE, Geneva.

van der Maaten, E., 2012. Climate sensitivity of radial growth in European beech (Fagus sylvatica L.) at different aspects in southwestern Germany. Trees - Struct. Funct. 26, 777-788.

van der Maaten, E., 2013. Thinning prolongs growth duration of European beech (Fagus sylvatica L.) across a valley in southwestern Germany. For. Ecol. Manage. 306, 135-141

van der Werf, G.W., Sass-Klaassen, U.G.W., Mohren, G.M.J., 2007. The impact of the 2003 summer drought on the intra-annual growth pattern of beech (Fagus sylvatica L.) and oak (Quercus robur L.) on a dry site in the Netherlands. Dendrochronologia 25, 103-112.

Vitasse, Y., Delzon, S., Dufrêne, E., Pontailler, J.Y., Louvet, J.M., Kremer, A., Michalet, R., 2009. Leaf phenology sensitivity to temperature in European trees: do within-species populations exhibit similar responses? Agric. For. Meteorol. 149, 735-744.

Weber, P., Bugmann, H., Pluess, A.R., Walthert, L., Rigling, A., 2013. Drought response and changing mean sensitivity of European beech close to the dry distribution limit. Trees - Struct. Funct. 27, 171-181.

Wigley, T.M.L., Briffa, K.R., Jones, P.D., 1984. On the average value of correlated time series with applications in dendroclimatology and hydrometeorology. J. Clim. Appl. Meteorol. 23, 201-213

Zang, C., Biondi, F., 2013. Dendroclimatic calibration in R: the bootRes package for response and correlation function analysis. Dendrochronologia 31, $68-74$. 